\title{
New large leptictid insectivore from the Late Paleogene of South Dakota, USA
}

Tj Meehan and Larry D. Martin

Acta Palaeontologica Polonica 57 (3), 2012: 509-518 doi: http://dx.doi.org/10.4202/app.2011.0035

From a skull and mandible, we describe a new genus and species of a primitive insectivore (Mammalia: Insectivora: Leptictida: Leptictidae). Its large body size and higher-crowned teeth indicate a different feeding ecology from other leptictid insectivores. With evidence of some heavy, flat wear on the molariform teeth, its shift in diet was likely to greater herbivory. Unlike the narrow snout of Blacktops, this new leptictid retains a broad snout, suggesting that small vertebrates were still important dietary components. The specimen was collected from the floodplain deposits of the lower or middle White River Group of South Dakota, which represent the latest Eocene to earliest Oligocene (Chadronian and Orellan North American Land Mammal “Ages”).

Key words: Mammalia, Leptictidae, Leptictis, Megaleptictis, Eocene, Oligocene, White River Group, South Dakota, North America.

TJ Meehan [tjmeehan333@yahoo.com], Research Associate, Section of Vertebrate Paleontology, Carnegie Museum of Natural History, 4400 Forbes Avenue, Pittsburgh, PA 15213, USA; Larry D. Martin [ldmartin@ku.edu], Division of Vertebrate Paleontology, Natural History Museum and Biodiversity Research Center, University of Kansas, Lawrence, KS 66045, USA.

This is an open-access article distributed under the terms of the Creative Commons Attribution License (for details please see creativecommons.org), which permits unrestricted use, distribution, and reproduction in any medium, provided the original author and source are credited. 
